\title{
THE EFFECTS OF ADRENERGIC-BLOCKING AGENTS ON THE PULMONARY CIRCULATION IN MAN
}

\author{
BY
}

\author{
J. MACKINNON, C. F. H. VICKERS, AND E. G. WADE
}

From the University Department of Cardiology, Manchester Royal Infirmary

The pulmonary blood vessels are richly inervated with fibres derived from both the sympathetic and parasympathetic nervous systems (Larsell, 1951; Mitchell, 1956) but attempts to demonstrate vasomotricity have yielded conflicting results. If the sympathetic fibres have a pulmonary vasomotor action, it might be anticipated that the administration of an adrenergic-blocking agent would have some demonstrable effect, especially if injected directly into the pulmonary artery. In 1953 Meriel et al. (1953) reported a fall in the pulmonary arterial pressure in normal subjects, in patients with mitral stenosis, and in a single case of primary pulmonary hypertension, following the injection of hydergine into the pulmonary artery through a cardiac catheter. (Hydergine consists of equal parts of the three hydrogenated alkaloids of ergot, dihydroergocornine, dihydroergocryptine, and dihydroergocristine.) They concluded that it exerted a direct action on the vasomotor system of the lungs. Using a similar technique Halmagy et al. (1953b) reported that hydergine had no effect on pulmonary dynamics: they found that dihydroergotamine, when injected into the pulmonary artery, caused a rise in pulmonary arterial systolic pressure and resistance, and concluded that this drug was capable of producing pulmonary vasoconstriction. Similar observations and conclusions regarding dihydroergotamine were reported by Halmagy et al. (1953a).

If adrenergic-blocking agents have any effect on the pulmonary circulation, then the manner in which they act has far-reaching implications. It seems important, therefore, to re-examine the action of such an agent, and our purpose is to report the results of seven observations in which hæmodynamic measurements were made following the injection of hydergine into the pulmonary artery through a cardiac catheter and four more in which priscol (2-benzyl-2-imidazoline) was injected. In two further observations priscol was administered orally.

Material and Methods. The observations were made on thirteen patients selected at random. Nine suffered from mitral stenosis alone and two from mitral stenosis complicated in one by incompetence and in the other by aortic stenosis. One patient suffered from pulmonary heart disease and one from slight pulmonary stenosis.

Cardiac catheterization was performed in the usual way and an indwelling needle placed in the brachial artery. Pressures were recorded by means of a capacitance manometer and intra-thoracic pressures referred to a point $5 \mathrm{~cm}$. below the sternal notch. Mean pressures were obtained by electrical filtration. In two cases (155 and 158) the systemic pressure was recorded simultaneously with the pulmonary arterial pressure. Cardiac outputs were estimated by the direct Fick procedure, the expired air being analysed on Haldane's instrument and blood gases by the Van Slyke-Neil manometric method. Vascular resistances were calculated from the following formulæ and expressed in c.g.s. units:

$$
\begin{array}{ll}
\text { Total Pulmonary Resistance (T.P.R.) } & =\frac{\left(\mathrm{PA}_{m}-5\right) \times 1332}{\mathrm{C} . \mathrm{O} . \mathrm{in} \mathrm{ml} . / \mathrm{sec} .} \\
\text { Pulmonary Vascular Resistance (P.V.R.) } & =\frac{\left(\mathrm{PA}_{m}-\mathrm{PCV}_{m}\right) \times 1332}{\mathrm{C} . \mathrm{O} . \text { in ml. } / \mathrm{sec} .} \\
\text { Peripheral Resistance } & =\frac{\mathrm{BA}_{m} \times 1332}{\mathrm{C} . \mathrm{O} . \mathrm{in} \mathrm{ml} / \mathrm{sec} .} \\
& 442
\end{array}
$$$$
\text { where C.O. = cardiac }
$$ 
output, $\mathrm{PA}_{m}=$ mean pulmonary arterial pressure in $\mathrm{mm} . \mathrm{Hg}, \mathrm{PCV}_{m}=$ mean pressure recorded with catheter tip wedged in peripheral lung fields in $\mathrm{mm}$. $\mathrm{Hg}$, and $\mathrm{BA}_{m}=$ mean brachial artery pressure in $\mathrm{mm} . \mathrm{Hg}$.

In ten cases basal estimations of cardiac output, pressure, and resistance were made. A dose of hydergine or priscol was then injected down the cardiac catheter into the main stem of the pulmonary artery over a period of two minutes. Continuous pressure recordings were made for the next six minutes, a further output estimation being made between the fourth and sixth minutes. In one observation, following the basal estimations, the subject performed graded work on a bicycle ergometer, the output, pressures, and resistances being estimated during the fifth to seventh minute of work. This was considered long enough for a steady state to be obtained. After a period of rest hydergine was injected through the catheter and the work repeated with further estimations during the fifth to seventh minutes. It was considered unjustifiable to wedge the catheter repeatedly to measure the P.C.V. pressure on account of the risk of causing pulmonary infarction.

In the remaining two observations priscol was administered orally. The procedure varied only in that the second output estimation was not taken until 15-20 minutes after administering the drug.

\section{RESULTS}

Table I shows the findings in six observations following the injection of various doses of hydergine through the cardiac catheter into the main stem of the pulmonary artery: there is no consistent effect upon the cardiac output, the pulmonary arterial pressure, or the total pulmonary resistance, irrespective of the initial levels. With the exception of Case 101 in which there was an increase of 24 beats a minute, there was also no effect upon the heart rate. The systemic resistance was

TABLE I

The Effect of Hydergine on the Pulmonary Circulation after Injection into the Pulmonary Artery

\begin{tabular}{|c|c|c|c|c|c|c|c|c|c|c|c|}
\hline $\begin{array}{l}\text { Case } \\
\text { No. }\end{array}$ & $\begin{array}{c}\text { Age } \\
\text { and sex }\end{array}$ & Rhythm & $\begin{array}{l}\text { Dose } \\
\text { in } \\
\mathrm{mg} .\end{array}$ & State & $\begin{array}{l}\text { Pulse } \\
\text { rate }\end{array}$ & $\begin{array}{c}\mathrm{O}_{2} \text { con- } \\
\text { sumption } \\
(\mathrm{ml} . / \mathrm{min} .)\end{array}$ & $\underset{\left(\begin{array}{l}\text { (vols. } \%) \\
\mathrm{O}_{2} \text { content }\end{array}\right.}{ }$ & $\begin{array}{c}\text { P.A. } \\
\mathrm{O}_{2} \text { content } \\
(\text { vols. } \%)\end{array}$ & $\begin{array}{c}\text { Cardiac } \\
\text { output } \\
\text { (1./min.) }\end{array}$ & $\underset{\text { mean }}{\text { P.A. }}$ & $\begin{array}{c}\text { Total pul- } \\
\text { monary } \\
\text { resistance } \\
\text { (c.g.s. units) }\end{array}$ \\
\hline \multirow{2}{*}{91} & \multirow{2}{*}{$31 \quad \mathrm{~F}$} & \multirow{2}{*}{$\mathbf{S}$} & \multirow{2}{*}{$0 \cdot 15$} & B & 90 & 269 & $16 \cdot 7$ & $13 \cdot 4$ & $8 \cdot 1$ & 41 & 355 \\
\hline & & & & A & 90 & 246 & $16 \cdot 7$ & $13 \cdot 2$ & $7 \cdot 0$ & 35 & 343 \\
\hline \multirow{2}{*}{100} & \multirow{2}{*}{$35 \mathrm{M}$} & \multirow{2}{*}{ A.F. } & \multirow{2}{*}{0.30} & B & 94 & 208 & $17 \cdot 7$ & $12 \cdot 5$ & $4 \cdot 0$ & 33 & 560 \\
\hline & & & & A & 90 & 243 & $17 \cdot 7$ & $12 \cdot 9$ & $5 \cdot 1$ & 37 & 517 \\
\hline \multirow{2}{*}{101} & \multirow{2}{*}{$45 \quad F$} & \multirow{2}{*}{$\mathbf{S}$} & \multirow{2}{*}{$0 \cdot 30$} & B & 90 & 177 & $16 \cdot 4$ & $13 \cdot 0$ & $5 \cdot 2$ & 19 & 220 \\
\hline & & & & A & 114 & 185 & $16 \cdot 4$ & $12 \cdot 4$ & $4 \cdot 6$ & 26 & 354 \\
\hline \multirow{2}{*}{102} & \multirow{2}{*}{$41 \mathrm{M}$} & \multirow{2}{*}{ A.F. } & \multirow{2}{*}{0.40} & B & 180 & 353 & $17 \cdot 2$ & $12 \cdot 2$ & $7 \cdot 0$ & 54 & 560 \\
\hline & & & & A & 174 & 280 & $17 \cdot 3$ & $12 \cdot 6$ & $6 \cdot 0$ & 53 & 647 \\
\hline \multirow{2}{*}{107} & \multirow{2}{*}{$35 \quad F$} & \multirow{2}{*}{$\mathbf{S}$} & \multirow{2}{*}{0.50} & B & 100 & 159 & $14 \cdot 8$ & $10 \cdot 9$ & $4 \cdot 1$ & 57 & 1002 \\
\hline & & & & A & 96 & 198 & $14 \cdot 7$ & $9 \cdot 2$ & $3 \cdot 6$ & 54 & 1009 \\
\hline \multirow{2}{*}{155} & \multirow{2}{*}{$34 \mathrm{~F}$} & \multirow{2}{*}{$\mathbf{S}$} & \multirow{2}{*}{0.60} & B & 86 & 235 & $13 \cdot 1$ & $9 \cdot 6$ & $6 \cdot 7$ & 32 & 323 \\
\hline & & & & A & 85 & 236 & $13 \cdot 2$ & $9 \cdot 3$ & $6 \cdot 0$ & 32 & 360 \\
\hline
\end{tabular}

S=Sinus rhythm. A.F.=Auricular fibrillation. $B=$ Basal. $A=$ After injection. B.A.=Brachial artery. P.A. = Pulmonary artery. 
calculated simultaneously only in Case 155 ; there was a fall from 826 to 560 dynes $/ \mathrm{sec} . / \mathrm{cm} .^{-5}$ after injecting $0.6 \mathrm{mg}$. of hydergine although the T.P.R. was virtually unaltered (Fig. 1).

Table II shows the effect of $0.6 \mathrm{mg}$. of hydergine injected into the pulmonary artery upon the pattern of the pulmonary vascular response to effort in a case of moderately severe mitral stenosis
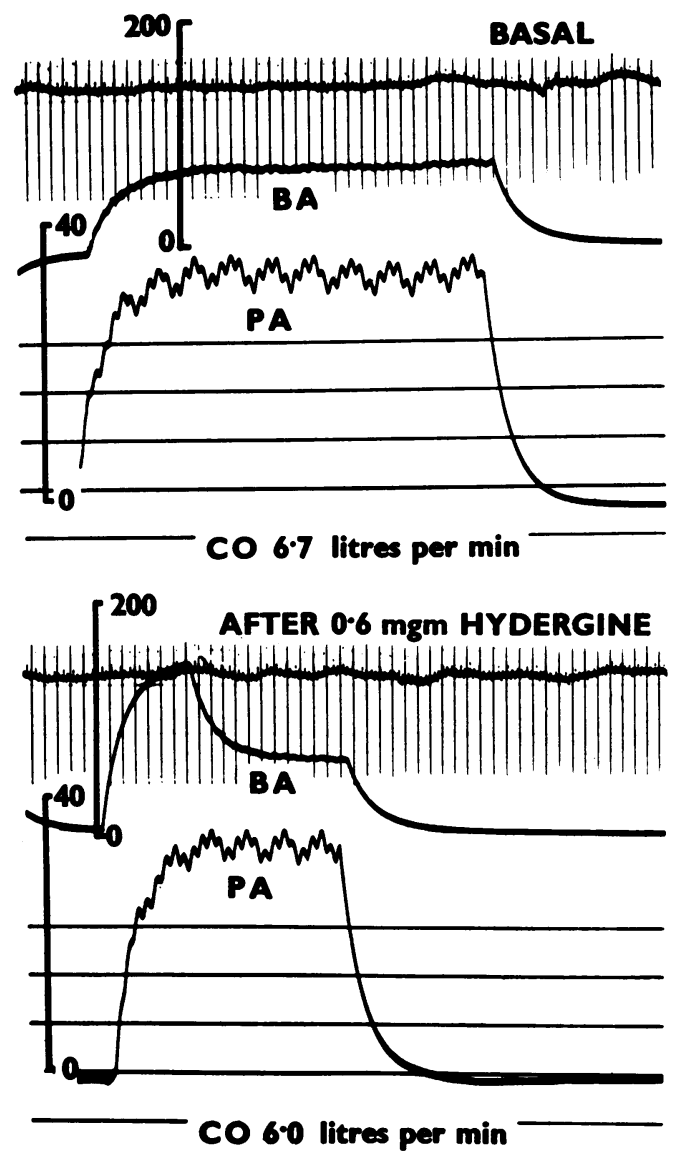

Fig. 1.-The effect of $0.6 \mathrm{mg}$. hydergine on brachial (BA) and pulmonary (PA) arterial pressures in $\mathrm{mm}$. Hg after injection into the pulmonary artery.

with a low initial pulmonary vascular resistance. Both before and after hydergine the same amount of exercise produced an identical increase in the pulmonary vascular resistances. The systemic resistance remained unchanged.

Table III shows the effect of priscol injected into the pulmonary artery, in four cases, in varying dosage. Irrespective of dose there was an invariable increase in heart rate of from 9 to 24 beats a minute. There were no consistent changes in cardiac output and, with two exceptions, the alterations in pulmonary arterial pressures and resistances were so slight as to be insignificant. In Case 135 there was a fall in total pulmonary resistance from 470 to 236 dynes $/ \mathrm{sec} . / \mathrm{cm} .^{-5}$. This was brought about by a fall in pulmonary arterial pressure and a rise in cardiac output, and at the same time the heart rate rose by 16 beats a minute. In Case 93 there was a striking increase in total pulmonary resistance from 1115 to 2540 dynes $/ \mathrm{sec} . / \mathrm{cm} .^{-5}$ brought about by a rise in mean pulmonary arterial pressure from 78 to $113 \mathrm{~mm}$. $\mathrm{Hg}$ and a fall in cardiac output from 5.3 to $3.41 . / \mathrm{min}$. More 
TABLE II

The Circulatory Response to Exercise Before and After Hydergine in a Patient with Mitral STENOSIS (CASE 158)

\begin{tabular}{|c|c|c|c|c|c|c|c|c|c|c|}
\hline State & Pulse & $\begin{array}{c}\mathrm{O}_{2} \text { con- } \\
\text { sumption } \\
\text { (ml./ } \\
\text { min.) }\end{array}$ & $\left\{\begin{array}{c}\mathrm{A}-\mathrm{V} \mathrm{O}_{2} \\
\text { diff. } \\
\text { (vols. \%) }\end{array}\right.$ & $\begin{array}{l}\text { Cardiac } \\
\text { output } \\
\text { (1./min.) }\end{array}$ & $\begin{array}{c}\text { P.A. } \\
\text { pressure } \\
(\mathrm{mm} . \mathrm{Hg}) \\
\mathrm{S}\end{array}$ & $\begin{array}{l}\text { P.C.V. } \\
\text { (mm.Hg) }\end{array}$ & $\begin{array}{c}\text { Pulm. } \\
\text { arteriol. } \\
\text { resist. } \\
\text { (c.g.s. units) }\end{array}$ & $\begin{array}{l}\text { Total } \\
\text { pulm. } \\
\text { resist. } \\
\text { (c.g.s. } \\
\text { units) }\end{array}$ & $\begin{array}{c}\begin{array}{c}\text { Systemic } \\
\text { pressure } \\
\text { (mm. Hg) }\end{array} \\
\text { S D M }\end{array}$ & $\begin{array}{l}\text { Peripheral } \\
\text { resistance } \\
\text { (c.g.s. } \\
\text { units) }\end{array}$ \\
\hline Rest & 69 & 270 & $5 \cdot 15$ & $5 \cdot 25$ & $\begin{array}{lll}47 & 21 & 31\end{array}$ & 25 & 91 & 396 & 1156358 & 880 \\
\hline Exercise .. & 90 & 492 & $7 \cdot 15$ & $6 \cdot 8$ & $\begin{array}{llll}80 & 35 & 56\end{array}$ & - & - & 600 & 1215471 & 840 \\
\hline $\begin{array}{l}\text { Exercise and } \\
\text { hydergine } \\
\text { 0.6 mg. into } \\
\text { P.A. .. }\end{array}$ & 95 & 500 & $7 \cdot 20$ & $6 \cdot 9$ & $\begin{array}{lll}83 & 32 & 56\end{array}$ & - & - & 592 & 1135270 & 810 \\
\hline
\end{tabular}

P.C.V.=Pulmonary capillary venous pressure. $\quad \mathrm{S}=$ Systolic. $\mathrm{D}=$ Diastolic. $\mathrm{M}=$ Mean. $\mathrm{P} . \mathrm{A} .=$ Pulmonary artery.

detailed analysis of this response (Fig. 2) shows that although the maximum increase in heart rate of 24 beats a minute occurred within 2 to 3 minutes, the pulmonary arterial pressure continued to rise until the fourth minute. Between the fifth and seventh minutes, when the response was at its height, the patient was very dyspnœic.

Administered orally, $50 \mathrm{mg}$. of priscol appears to have no effect on circulatory dynamics (Table III). In Case 149 the cardiac output was unusually low on both estimations and in consequence the total pulmonary resistance was remarkably high. This is largely due to a very low oxygen consumption. It was felt that this was possibly erroneous but no fault could be found in the mouthpiece, valves, connective tubing, or Tissot spirometer.

\section{Discussion}

The dosage of hydergine used was of the same order as that employed by Halmagy et al. (1953b) and also by Meriel et al. (1953). Barcroft and Swan (1953) found that 0.6 mg. i.v. of either dihydroergocornine or hydergine was sufficient to cause peripheral vasodilation with a considerable increase in skin blood flow, while Gibbs (1952) observed that as little as $0.3 \mathrm{mg}$. i.v. caused a fall in systemic blood pressure. We also found that $0.6 \mathrm{mg}$. produced a fall in systemic blood pressure (Fig. 1) and it is probable that this is a fully effective dose.

We can find no evidence that hydergine is a pulmonary vasodilator. There is no constant effect, irrespective of the initial total pulmonary resistance. The failure to block or otherwise modify the anticipated increase in pulmonary resistance on effort in Case 158 is also against the concept that hydergine acts upon the pulmonary vasomotor system. It is possible that this type of response to effort, which occurs in some cases of mitral stenosis, may be independent of active vasomotor narrowing, having its origin in the increased rigidity of structurally abnormal vessels and the decreasing fluidity of blood in small-bore tubes (Eliasch, Wade, and Werko, 1952), but it is unlikely that this is a wholly satisfactory explanation when the resting vascular resistance is normal. We are therefore unable to agree with Meriel et al. (1953) that hydergine has a specific pulmonary vasodilator effect; or, as they claim, that it will serve to differentiate " functional " from " irreversible " narrowing of the pulmonary arterioles in mitral stenosis. In one case (101) the total pulmonary resistance rose by 60 per cent but this was the only case in which the heart rate increased, and it is possible that this shortening of diastolic filling time may have been the reason. Our observations support those of Halmagy et al. (1953b), namely, that hydergine has no constant effect on the cardiac output, the pulmonary arterial pressure, or the pulmonary resistance. 
Halmagy et al. (1953a) reported that dihydroergotamine acted as a pulmonary vasoconstrictor. Ergotamine is known to exert a direct action on smooth muscle and, although an adrenergic-blocking agent, it acts, by virtue of this direct effect on vascular smooth muscle, as a vasoconstrictor (Goodman and Gilman, 1955). This undesirable side effect is less marked in ergotoxine and is further reduced by hydrogenation. Thus hydrogenated ergotoxine (hydergine) no longer possesses an overall

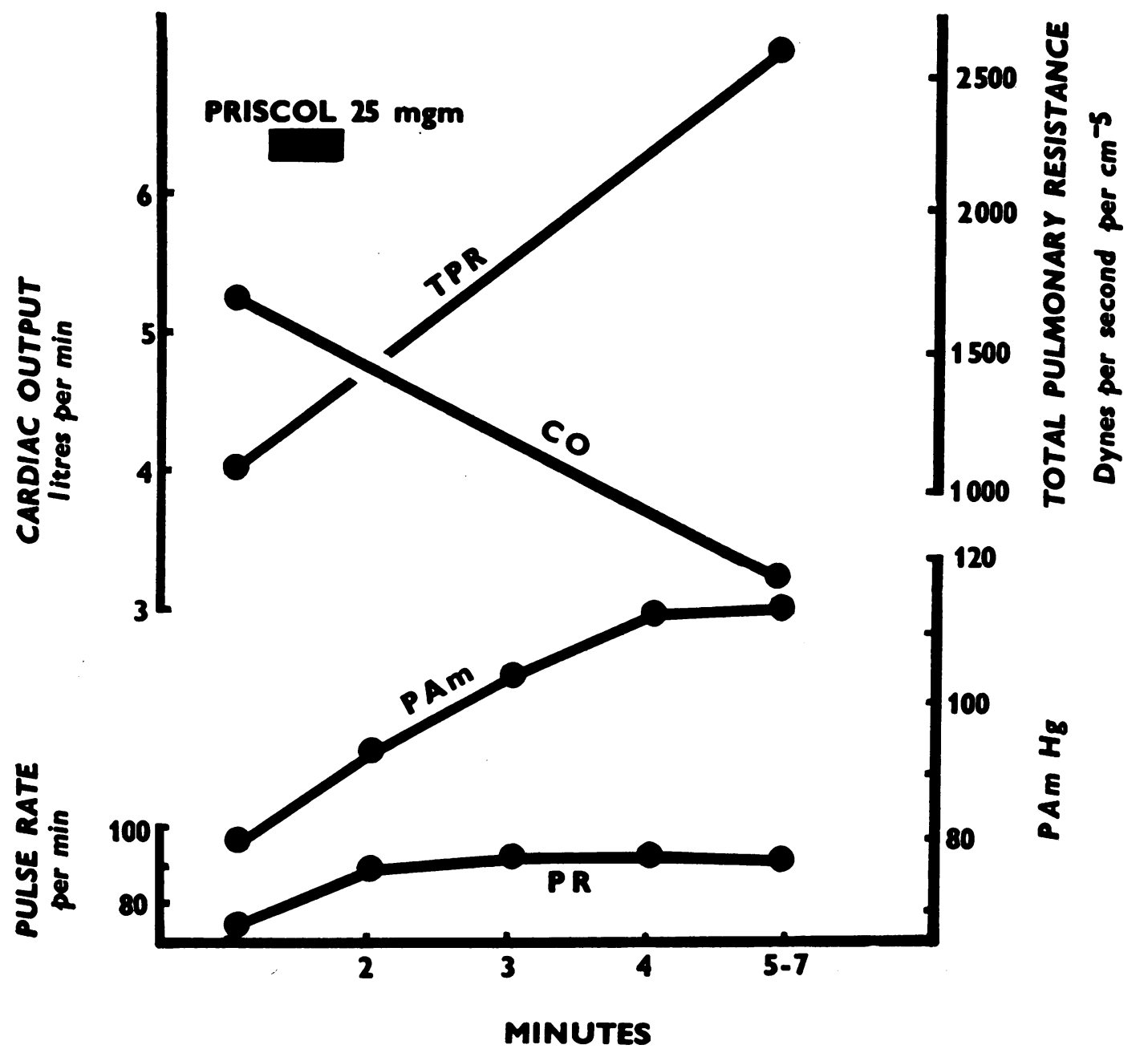

FIG. 2.-The circulatory response to injection of $25 \mathrm{mg}$ of priscol into the pulmonary artery of a patient with mitral stenosis.

vasoconstrictor effect although dihydroergotamine still does. It is probably this direct action on the smooth muscle present in the walls of pulmonary arteries greater than $100 \mu$ in diameter that is responsible for the vasoconstrictor effect observed by Halmagy et al. (1953a). There seems to be no justification for regarding this effect as evidence for the participation of the sympathetic nervous system in the genesis of established or labile pulmonary hypertension.

Priscol is also an adrenergic-blocking agent but has more undesirable side effects than hydergine, such as tachycardia, flushing, and conjunctival injection (Wakim et al., 1950; Barcroft and Swan, 1953; Goodman and Gilman, 1955). We selected it for trial on account of the claim by Dresdale 
TABLE III

The Effect of Priscol on the Pulmonary Circulation

\begin{tabular}{|c|c|c|c|c|c|c|c|c|c|c|c|c|}
\hline $\begin{array}{l}\text { Case } \\
\text { No. }\end{array}$ & $\begin{array}{l}\text { Age } \\
\text { and } \\
\text { sex }\end{array}$ & Disease & $\begin{array}{c}\text { Dose } \\
\text { in } \\
\mathrm{mg} .\end{array}$ & $\begin{array}{c}\text { Route } \\
\text { of } \\
\text { admin. }\end{array}$ & State & $\begin{array}{c}\text { Pulse } \\
\text { rate }\end{array}$ & $\begin{array}{c}\mathrm{O}_{2} \\
\text { consump- } \\
\text { tion } \\
\text { (ml./min.) }\end{array}$ & $\begin{array}{c}\text { B.A. } \\
\mathrm{O}_{2} \text { con- } \\
\text { tent } \\
(\text { vols. } \%)\end{array}$ & $\begin{array}{c}\text { P.A. } \\
\mathrm{O}_{2} \text { con- } \\
\text { tent } \\
(\text { vols. } \% \text { ) }\end{array}$ & $\begin{array}{c}\text { Cardiac } \\
\text { output } \\
\text { (l./min.) }\end{array}$ & $\begin{array}{c}\text { P.A. } \\
\text { mean } \\
(\mathrm{mm} . \\
\mathrm{Hg})\end{array}$ & $\begin{array}{c}\text { Total } \\
\text { pulmonary } \\
\text { resistance } \\
\text { (c.g.s. units) }\end{array}$ \\
\hline \multirow{2}{*}{64} & \multirow{2}{*}{$52 \mathrm{M}$} & \multirow{2}{*}{ Cor Pul. } & \multirow{2}{*}{25} & \multirow{2}{*}{ P.A. } & B & 97 & 225 & $14 \cdot 8$ & $11 \cdot 1$ & $6 \cdot 1$ & 34 & 386 \\
\hline & & & & & A & 110 & 220 & $15 \cdot 8$ & $11 \cdot 5$ & $5 \cdot 1$ & 29 & 376 \\
\hline \multirow{2}{*}{93} & \multirow{2}{*}{$34 \mathrm{M}$} & \multirow{2}{*}{ M.S. } & \multirow{2}{*}{25} & \multirow{2}{*}{ P.A. } & B & 72 & 210 & $12 \cdot 2$ & $8 \cdot 2$ & $5 \cdot 3$ & 78 & 1115 \\
\hline & & & & & A & 96 & 177 & $12 \cdot 3$ & $7 \cdot 1$ & $3 \cdot 4$ & 113 & 2540 \\
\hline \multirow{2}{*}{135} & \multirow{2}{*}{$48 \quad F$} & \multirow{2}{*}{ M.S. } & \multirow{2}{*}{$12 \cdot 5$} & \multirow{2}{*}{ P.A. } & B & 114 & 221 & $17 \cdot 1$ & $12 \cdot 9$ & $5 \cdot 3$ & 36 & 470 \\
\hline & & & & & $\bar{A}$ & 130 & 353 & $16 \cdot 6$ & $12 \cdot 6$ & $8 \cdot 8$ & 31 & 236 \\
\hline \multirow{2}{*}{140} & \multirow{2}{*}{$24 \mathrm{~F}$} & \multirow{2}{*}{$\begin{array}{c}\text { Slight } \\
\text { P.S. }\end{array}$} & \multirow{2}{*}{$17 \cdot 5$} & \multirow{2}{*}{ P.A. } & B & 66 & 276 & $15 \cdot 3$ & $12 \cdot 0$ & $8 \cdot 4$ & 8 & 24 \\
\hline & & & & & A & 75 & 370 & $15 \cdot 4$ & $12 \cdot 0$ & $10 \cdot 9$ & 7 & 15 \\
\hline \multirow[t]{2}{*}{148} & \multirow[t]{2}{*}{$41 \quad F$} & \multirow{2}{*}{$\begin{array}{l}\text { M.S., } \\
\text { M.I. }\end{array}$} & \multirow[t]{2}{*}{50} & \multirow[t]{2}{*}{ Oral } & B & 70 & 232 & $17 \cdot 5$ & $12 \cdot 5$ & $4 \cdot 6$ & 63 & 1000 \\
\hline & & & & & A & 80 & 301 & $17 \cdot 2$ & $11 \cdot 4$ & $5 \cdot 2$ & 61 & 860 \\
\hline \multirow[t]{2}{*}{$149 *$} & \multirow[t]{2}{*}{$41 \quad F$} & \multirow{2}{*}{$\begin{array}{l}\text { M.S., } \\
\text { A.S. }\end{array}$} & \multirow[t]{2}{*}{50} & \multirow[t]{2}{*}{ Oral } & B & 135 & 99 & 14.95 & $6 \cdot 4$ & $1 \cdot 15$ & 68 & 4560 \\
\hline & & & & & A & 135 & 85 & $14 \cdot 15$ & $5 \cdot 9$ & 1.03 & 68 & 5700 \\
\hline
\end{tabular}

Cor Pul. $=$ Cor pulmonale. B.A., P.A. $=$ Brachial or pulmonary artery. A.S., M.S., P.S. $=$ Aortic, mitral, or pulmonary stenosis. $\mathbf{B}=$ Basal. $\mathrm{A}=$ After administration of drug. M.I. $=$ Mitral incompetence. C.O.=Cardiac output.

* Case 149 had atrial fibrillation: all the others had normal sinus rhythm.

et al. (1954) that when injected into the pulmonary artery it possesses a unique relaxant effect on the pulmonary arterioles in primary pulmonary hypertension, a disease characterized by a primary increase in pulmonary vascular hindrance (Wade, 1954). Dresdale et al. (1954) also reported a similar effect in a case of atrial septal defect complicated by pulmonary hypertension. Administered by the same route, we found the effect to be variable. Thus, in two cases there was no change, in one (Case 135) there was an appreciable fall and in the other (Case 93) there was a sharp rise in pulmonary arterial pressure and resistance, and a fall in cardiac output (Fig. 2); for several minutes the patient's condition caused anxiety. In a case of severe mitral stenosis with gross pulmonary hypertension previously investigated we observed a similar response to the intra-pulmonary arterial injection of $25 \mathrm{mg}$. of priscol, also with considerable embarrassment to the patient. (This case is not included in the series on account of failure to obtain satisfactory output estimations.) It might be thought that the associated tachycardia, by reducing diastolic filling time, could be an important factor, but this mechanism could only act by raising the mean left atrial, and therefore the pulmonary capillary pressure. The osmotic pressure of the blood, approximately $35 \mathrm{~mm} . \mathrm{Hg}$, limits the extent to which the capillary pressure can rise and active vasoconstriction has to be invoked to explain the large increase in total pulmonary resistance. A rise in left atrial pressure, acting through an unknown receptor-effector mechanism, might well cause a vasoconstrictive response in the pulmonary arterioles, but the temporal disproportion between the rise in pulse rate and pulmonary arterial pressure (Fig. 2) is against this explanation. It seems more probable that priscol has an inconstant direct effect upon arterial smooth muscle. It is important to recognize that this effect may occur and that intravenous or intra-arterial priscol therapy may therefore be dangerous in cases of mitral stenosis with severe pulmonary hypertension. 


\section{CONCLUSIONS}

We have found that the adrenergic-blocking agents hydergine and priscol, when injected into the pulmonary artery, have no constant effect on pulmonary vascular dynamics, irrespective of the initial level of the total pulmonary resistance. There is, therefore, no evidence that, in the cases studied, the pulmonary vascular pattern was dependent on the excitor function of sympathetic nerves. In one case of severe mitral stenosis with gross pulmonary arterial hypertension, priscol caused a sharp rise in pulmonary arterial pressure and resistance and a fall in cardiac output, the patient becoming apprehensive and dyspnœic. We have encountered this type of response once previously in a similar case. We consider that it is due to a direct effect of priscol on arterial smooth muscle and we suggest that intravenous or intra-arterial priscol may be dangerous in this type of case. Oral priscol in a dose of $50 \mathrm{mg}$. appears to be without effect.

\section{SUMMARY}

The results of eleven observations are reported in which measurements of the cardiac output and pulmonary pressures were made before and after the injection into the pulmonary artery of one of the adrenergic-blocking agents hydergine (equal parts of the three hydrogenated alkaloids of ergot, dihydroergocornine, dihydroergocryptine, and dihydroergocristine) or priscol (2-benzyl-2-imidazoline). In two further observations priscol was administered orally.

Hydergine has no appreciable effect, irrespective of the initial level of the pulmonary resistance. Priscol has a varying effect and, in one case of severe mitral stenosis with gross pulmonary hypertension caused anxiety by producing a sharp rise in pulmonary resistance and a fall in cardiac output. It is suggested that this is due to a direct effect on pulmonary arterial smooth muscle. By mouth, priscol appears ineffective.

The results yield no evidence that the sympathetic nervous system is concerned in the maintenance of the pulmonary vascular pattern irrespective of whether the pulmonary resistance is normal or raised.

We thank our patients who, without exception, were willing to co-operate in our observations. We also thank Dr. Morgan Jones for his interest and help.

\section{REFERENCES}

Barcroft, H., and Swan, J. H. C. (1953). Sympathetic Control of Human Blood Vessels. London, Arnold. Dresdale, D. T., Michtom, R. J., and Schultz, M. (1954). Bull. N.Y. Acad. Med., 39, Second series, 195. Eliasch, H., Wade, G., and Werko, L. (1952). Circulation, 5, 271.

Gibbs, D. F. (1952). Brit. Heart J., 14, 77.

Goodman, L. S., and Gilman, A. (1955). The Pharmacological Basis of Therapeutics. New York, Mcmillan. Halmagy, D., Felkai, B., Ivanyi, J., Zsoter, T., Tenyi, M., and Szucs, Z. (1953a). Brit. Heart J., 15, 15. _- Ivanyi, J., Felkai, B., Zsoter, T., Tenyi, M., and Szucs, Z. (1953b). Scand. J. Clin. Lab. Invest., 53, 85. Larsell, O. (1951). Anatomy of the Nervous System. New York, Appleton-Century-Crofts. Meriel, P., Botinelli, R., Calazel, P., and Cassagneau, J. (1953). Arch. Mal. Caur, 46, 329.

Mitchell, G. A. G. (1956). Cardiovascular Innervation.

Wade, G. (1954). Quart. J. Med., 23, 456.

Wakim, K. G., Peters, G. A., and Horton, B. T. (1950). J. Lab. Clin. Med., 35, 50. 